\title{
STUDY TEA PRODUCTION FROM LIBERICA GREEN COFFEE SKIN IN TUNGKAL, JAMBI AS A REFRESHING DRINK
}

\author{
Emanauli $^{\#}$, Rudi Prihantoro* \\ Department of Agro Industrial Technology, Faculty of Agricultural Technology, Jambi University \\ Jl. Tri Brata KM 11 Pondok Meja, Mestong, Muaro Jambi, Indonesia \\ masrudiprihantoro@gmail.com
}

\begin{abstract}
Coffea Liberica is a coffee plant that grow at lowlands and specifically on peatlands. Unlike Arabica and Robusta, Liberica coffee is large and able to grow up to 9 meters in height. Tea as a refreshing drink made from coffee skin which called cascara tea, had been developed in Indonesia and around the world. However, tea that made from green coffee skin is rarely been produced. This study used vary drying temperature $(70,80,90 \quad)$ and time $(12,18,24$ hours). Refreshing drink products had a yellowish brown color with a hint of bitterness and tea leaves aroma. Drying condition with temperature of 90 and 12 hours of time duration is resulted in the most preferred beverage. The dried green coffee skin had 5.73\% moisture content, $12.58 \%$ crude fiber, $4.78 \%$ ash content, $\mathrm{pH} 3.8,9.95$ of total polyphenols and 86.08 of antioxidant content.
\end{abstract}

Keywords: Liberica coffee, refresing drink, tea made from coffee skin.

\section{INTRODUCTION}

Kopi liberika tungkal komposit merupakan kopi yang dikembangkan dan diproduksi oleh petani jambi khususnya di Kabupaten Tanjung Jabung Barat yang telah mendapatkan hak paten dari Kementrian Hukum dan HAM RI. Limbah kulit kopi belum dimanfaatkan petani secara optimal (Efendi, 2014). Pemanfaatan bisa memiliki daya jual yang tinggi. Contohnya seperti limbah kulit biji kopi dapat dimanfaatkan menjadi minuman teh dengan cara dikeringkan dan di kemas dalam kemasan yang menarik.

Biji kopi diolah sedemikian rupa sehingga nantinya dapat dimanfaatkan untuk dikonsumsi oleh manusia. Pada proses tersebut ada bagian buah yang dibuang yaitu pulp (mesocarp), skin (eksocarp), mucilage dan parchment (endocarp) dan bagian-bagian tersebut dapat disebut dengan limbah kulit biji kopi yang biasanya dibuang dimana dari total berat buah kopi yang diolah menjadi biji kopi sekitar $40-45 \%$ dihasilkan kulit biji kopi. Bila hasil panen sebanyak 1000kg kopi segar berkulit, maka yang menjadi biji kopi sekitar 400-500kg dan sisanya adalah hasil sampingan berupa kulit kopi. Limbah kulit kopi belum dimanfaatkan petani secara optimal (Efendi, 2014). Pemanfaatan bisa memiliki daya jual yang tinggi.
Contohnya seperti limbah kulit biji kopi dapat dimanfaatkan menjadi minuman teh dengan cara dikeringkan dan dikemas dalam kemasan yang menarik.

Komposisi penyusun dari skin, pulp, parchment adalah karbohidrat (35\%), protein $(5,2 \%)$, fiber $(30,8 \%)$ dan mineral $(10,7 \%)$ sedangkan bagian mucilage mengandung air $(84,2 \%)$, protein $(8,9 \%)$, gula $(4,1 \%)$ dan abu $(0,7 \%)$. Selain itu, limbah kulit biji kopi ini juga mengandung beberapa senyawa metabolit sekunder yaitu seperti dari kafein dan golongan polifenol. Dari beberapa penelitian, senyawa polifenol yang ada pada limbah ini adalah flavan-3-ol, asam hidroksinamat, flavonol, antosianidin, katekin, epikatekin, rutin, tanin, asam ferulat (Esquivel \& Jimenez, 2011).

Polifenol dapat diartikan suatu senyawa kimia yang umumnya terdapat pada bahan alam dimana struktur dasarnya memiliki gugus aromatic yang terikat satu atau lebih gugus $\mathrm{OH}$. Senyawa ini telah menjadi pusat perhatian oleh para ilmuwan karena memiliki banyak manfaat bagi kesehatan.

Antioksidan dapat diartikan sebagai suatu senyawa yang memiliki kemampuan melindungi sel dari efek berbahaya radikal bebas oksigen reaktif dengan cara menghambat terjadinya suatu oksidasi yaitu bereaksi dengan radikal 
bebas yang reaktif sehingga membentuk radikal bebas tak reaktif.

Melalui penelitian ini penulis berupaya untuk mengembangkan minuman olahan dari kulit biji kopi liberika tungkal komposit sebagai minuman tradisional jambi sehingga dapat mengurangi limbah dan dapat meningkatkan produktivitas pembuatan teh kulit biji kopi.

\section{MATERIAL AND METHODS}

\section{A. Bahan dan Alat}

Bahan baku yang digunakan dalam penelitian ini adalah kulit biji kopi hijau Liberika dari Kabupaten Tanjung Jabung Barat Propinsi Jambi, dan mineral water. Bahan-bahan untuk keperluan analisis . Alat-alat yang digunakan yaitu oven, neraca analitik, alat-alat gelas kimia, peralatan analisa dan peralatan pengolahan teh kulit kopi liberika hijau .

\section{B. Rancangan Penelitian}

Penelitian ini menggunakan Rancangan acak lengkap faktorial. Dengan perlakuan suhu $\left(70,80,90^{\circ} \mathrm{C}\right)$ dan waktu $(12,18,24$ jam $)$. Terdiri dari tiga tahapan penelitian. Tahap pertama yaitu tahap uji proksimat (AOAC, 1995) terhadap bubuk teh yang dihasilkan meliputi kadar air dan kadar abu. Tahap kedua yaitu tahap pengujian kimia terhadap minuman penyegar berupa $\mathrm{pH}$ (Apryantono, 1989), total fenol (Andarwulan, 1999), dan uji aktifitas antioksidan (Selvi, 2003). Tahap ketiga yaitu tahap pengujian organoleptik meliputi uji kesukan dan uji pembeda. Data yang diperoleh kemudian dianalisis menggunakan ANOVA (Analysis Of Variance). Bila hasilnya berbeda nyata akan dilanjutkan dengan uji Duncan. Aplikasi yang digunakan adalah program SPSS16.

\section{Proses Pembuatan Teh Kulit Biji Kopi Liberika Hijau (Simanjuntak, 2014) \\ Penelitian ini mengunakan kopi liberika} tungkal komposit yang masih hijau. Kopi dibersihkan dan dicuci, lalu ditiriskan kemudian dikupas dan diambil kulitnya. Kulit yang sudah dipisahkan dari biji kopi dipotong dengan ukuran $0,5 \mathrm{~cm}$ dan dikeringkan menggunakan oven dengan perlakuan suhu dan waktu yang telah ditetapkan.
D. Proses Pembuatan Minuman Penyegar Teh Kulit Biji Kopi Liberika Hijau (Supriyanto et al, 2014)

Minuman penyegar yang dimaksud adalah air rebusan teh kulit biji kopi liberika hijau, dibuat dengan cara merebus teh kulit biji kopi kering sebanyak $2 \mathrm{~g}$ ke dalam air mendidih sebanyak $200 \mathrm{ml}$. Cara perebusan dipilih karena dengan metode ini diperoleh air teh kulit biji kopi yang lebih pekat dibandingkan dengan air teh kulit biji kopi yang disajikan dengan cara penyeduhan.

\section{RESULT AND DISCUSSION}

\section{A. Analisis Proksimat}

Kadar air teh kulit biji kopi hijau liberika yang dibuat dari berbagai variasi perlakuan adalah seperti pada Tabel 1 . Dari Tabel tersebut diketahui bahwa teh kulit kopi hijau liberika dari berbagai variasi perlakuan memiliki kadar air pada kisaran 4.26 - 15.06\%. dengan adanya teh kulit kopi yang memiliki kadar air $15 \%$ maka akan mudah terjadi kerusakan akibat serangan mikroba.

Tabel 1. Kadar Air Teh Kulit Kopi Liberika Hijau

\begin{tabular}{cccc}
\hline \multirow{2}{*}{$\begin{array}{c}\text { Waktu } \\
(\text { Jam })\end{array}$} & $70^{\circ} \mathrm{C}$ & $80^{\circ} \mathrm{C}$ & $90^{\circ} \mathrm{C}$ \\
\cline { 2 - 4 } & $15.06^{\mathrm{e}}$ & $9.71^{\mathrm{d}}$ & $5.73^{\mathrm{ab}}$ \\
\hline 12 & $8.25^{\mathrm{cd}}$ & $7.03^{\mathrm{bc}}$ & $4.98^{\mathrm{a}}$ \\
\hline 18 & $7.38^{\mathrm{bc}}$ & $5.71^{\mathrm{ab}}$ & $4.26^{\mathrm{a}}$ \\
\hline 24 & & &
\end{tabular}

Kadar air teh kering yang dipersyaratkan oleh SNI maksimal adalah $8 \%(\mathrm{~b} / \mathrm{b})$. sementara itu pabrik teh di Indonesia umumnya menetapkan standar kadar air bubuk teh yang aman pada kisaran 3-5\%. Semakin tinggi suhu dan semakin lama waktu sangat berpengaruh terhadap kadar air teh. Kadar air teh tertinggi ada pada pengeringan suhu $70^{\circ} \mathrm{C}$ waktu 12 jam. $15.06 \%$ merupakan kadar air yang tinggi untuk teh karena akan berakibat pada penyimpanan yang tidak tahan lama.

Kadar abu teh kulit kopi hijau liberika dengan berbagai variasi perlakuan disajikan pada Tabel 2. Dari tabel dapat dilihat bahwa kadar abu teh berkisar 4,16 - 6,40\%. Berdasarkan kriteria SNI kadar abu yang terdapat dalam teh maksimal adalah $8 \%$, 
sehingga secara keseluruhan setiap sampel teh kulit kopi hijau liberika yang diuji telah sesuai dengan SNI.

Tabel 2. Kadar Abu Teh Kulit Kopi Liberika Hijau

\begin{tabular}{cccc}
\hline Waktu & \multicolumn{3}{c}{ Suhu } \\
\cline { 2 - 4 }$($ Jam) & $70^{\circ} \mathrm{C}$ & $80^{\circ} \mathrm{C}$ & $90^{\circ} \mathrm{C}$ \\
\hline 12 & $6.40^{\mathrm{c}}$ & $4.16^{\mathrm{a}}$ & $4.78^{\mathrm{abc}}$ \\
\hline 18 & $5.39^{\mathrm{abc}}$ & $4.50^{\mathrm{ab}}$ & $4.30^{\mathrm{a}}$ \\
\hline 24 & $6.21^{\mathrm{bc}}$ & $4.45^{\mathrm{ab}}$ & $4.49^{\mathrm{ab}}$ \\
\hline
\end{tabular}

Kadar abu merupakan campuran dari komponen anorganik atau mineral yang terdapat pada suatu bahan pangan. Bahan pangan terdiri dari $96 \%$ bahan anorganik dan air, sedangkan sisanya merupakan unsur - unsur mineral. Unsur juga dikenal sebagai zat organik atau kadar abu. Kadar abu tersebut dapat menunjukkan total mineral dalam suatu bahan pangan. Baha- bahan organik dalam proses pembakaran akan terbakar tetapi komponen anorganiknya tidak, karena itulah disebut sebagai kadar abu (Zahro, 2013).

\section{B. $p H$}

Pengujian $\mathrm{pH}$ pada penelitian ini ditentukan untuk mengetahui $\mathrm{pH}$ yang berkaitan dengan stabilitas antosianin kulit buah kopi sesuai dengan literature yaitu Antosianin akan berubah warna seiring dengan perubahan nilai $\mathrm{pH}$. Pada $\mathrm{pH}$ tinggi antosianin cenderung berwarna biru atau tidak berwarna, kemudian cenderung berwarna merah pada $\mathrm{pH}$ rendah (Elbe, 1996). Nilai pH minuman penyegar teh kulit kopi hijau liberika dapat dilihat pada Gambar 1.

$\mathrm{pH}$ minuman penyegar teh kulit biji kopi liberika hijau dari berbagai variasi perlakuan berkisar antara 3,8 sampai 4,0. Dari Gambar 1 dapat dilihat bahwa tidak ada pengaruh suhu dan waktu pengeringan terhadap nilai keasaman dari teh kulit kopi. Semakin rendah nilai $\mathrm{pH}$ menunjukkan semakin tinggi kandungan asam yang terdapat pada minumam penyegar teh kulit kopi yang berperan dalam pembentukan aroma dan citarasa.

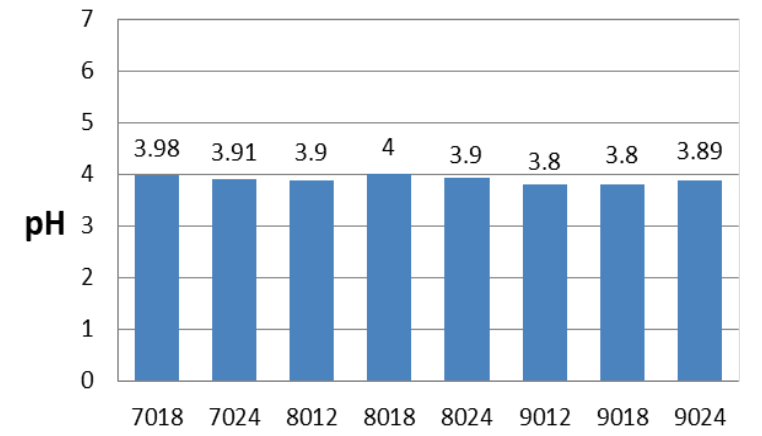

\section{Gambar 1. Analisis pH Minuman Penyegar Teh Kulit Kopi Hijau Liberika.}

\section{Kadar Polifenol}

Kadar total polifenol pada minuman penyegar teh kulit biji kopi liberika tungkal dari berbagai perlakuan disajikan pada Tabel 3 .

Tabel 3. Kadar Total Fenol Minuman Penyegar

\begin{tabular}{|c|c|c|c|c|c|}
\hline \multicolumn{2}{|c|}{ Perlakuan } & \multicolumn{2}{|c|}{ Absorbansi } & \multirow{2}{*}{$\begin{array}{l}\text { Rata- } \\
\text { rata }\end{array}$} & \multirow[b]{2}{*}{$\begin{array}{c}\% \text { Total } \\
\text { Fenol }\end{array}$} \\
\hline Suhu & Waktu & $\begin{array}{c}\text { Ulangan } \\
1 \\
\end{array}$ & $\begin{array}{c}\text { Ulangan } \\
\mathbf{2} \\
\end{array}$ & & \\
\hline \multirow{2}{*}{70} & 18 & 0.434 & 0.448 & 0.441 & 9.95 \\
\hline & 24 & 0.434 & 0.447 & 0.441 & 9.94 \\
\hline \multirow{3}{*}{80} & 12 & 0.437 & 0.427 & 0.432 & 9.84 \\
\hline & 18 & 0.434 & 0.438 & 0.436 & 9.89 \\
\hline & 24 & 0.444 & 0.463 & 0.454 & 10.11 \\
\hline \multirow{3}{*}{90} & 12 & 0.431 & 0.451 & 0.441 & 9.95 \\
\hline & 18 & 0.457 & 0.431 & 0.444 & 9.99 \\
\hline & 24 & 0.438 & 0.452 & 0.445 & 10.00 \\
\hline
\end{tabular}

Dari Tabel 3. menunjukkan bahwa kadar fenol minuman penyegar teh kulit biji kopi liberika hijau semakin meningkat dengan lamanya waktu pengeringan. Perlakuan suhu 80 ${ }^{\circ} \mathrm{C}$ dan waktu 24 jam memiliki total fenol paling tinggi sedangkan perlakuan suhu $80{ }^{\circ} \mathrm{C}$ dan waktu 12 jam memiliki total fenol terendah yaitu 9,84 .

\section{Kadar Antioksidan}

Hasil pengamatan aktivitas antioksidan pada minuman penyegar teh kulit biji kopi liberika hijau dapat dilihat pada Gambar 2 yang menyatakan bahwa aktivitas antioksidan minuman penyegar memiliki nilai tertinggi pada pengeringan dengan suhu $90{ }^{\circ} \mathrm{C}$ dan waktu 24 
jam yaitu $87,69 \%$ sedangkan untuk nilai terendah terdapat pada pangeringan dengan suhu $90{ }^{\circ} \mathrm{C}$ dan waktu 12 jam yaitu $86,08 \%$. Aktivitas antioksidan seluruh sampel minuman penyegar lebih kecil dibandingkan dengan standar (vitamin C) $(89.16 \%)$.

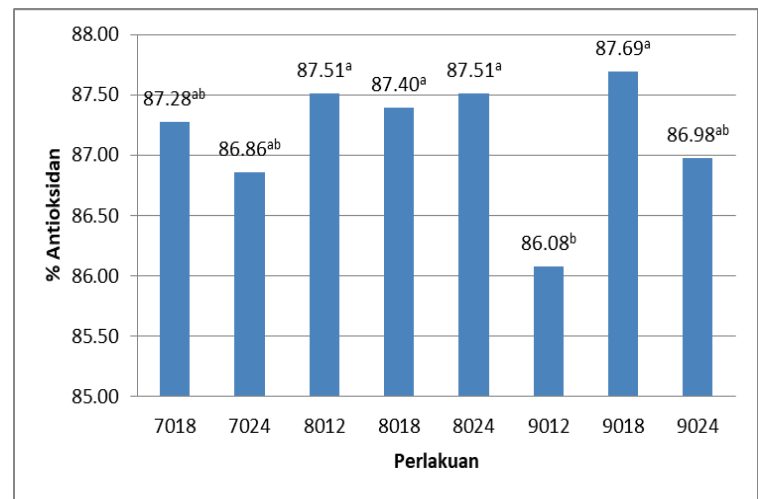

Gambar 2. Kadar Antioksidan Minuman Penyegar

Lama pengeringan berpengaruh terhadap semakin besarnya kemampuan dalam menangkap radikal bebas DPPH. Hal ini dikarenakan pada proses pengeringan terjadi inaktivasi enzim polifenol oksidase sehingga oksidasi senyawa fenol terhambat. Enzim ini berpengaruh terhadap perubahan flavanol pada daun teh menjadi senyawa polifenol pada teh hitam (Ardiansyah, 2012). Semakin lama pengeringan maka semakin sedikit senyawa fenol yang berubah, begitu pula sebaliknya.

\section{Uji Kesukaan Minuman Penyegar Air Rebusan Teh Kulit Biji Kopi}

Hasil uji kesukaan air rebusan teh kulit biji kopi dari berbagai perlakuan dapat dilihat pada dan Gambar 3. Berdasarkan data dari gambar tersebut diketahui bahwa air rebusan teh kulit biji kopi yang dibuat dengan suhu $90{ }^{\circ} \mathrm{C}$ dan waktu 12 jam, warna dan aromanya paling disukai. Rasa pahit air rebusan yang paling disukai adalah air rebusan teh kulit biji kopi dengan suhu $70{ }^{\circ} \mathrm{C}$ dan $80^{\circ} \mathrm{C}$ pada waktu 24 jam, sementara itu untuk rasa sepat yang paling disukai adalah air rebusan teh dengan suhu 80 dan waktu 18 jam. Sehingga dapat disimpulkan bahwa air rebusan teh yang paling disukai adalah air rebusan yang dibuat suhu $90{ }^{\circ} \mathrm{C}$ dan waktu 12 jam.

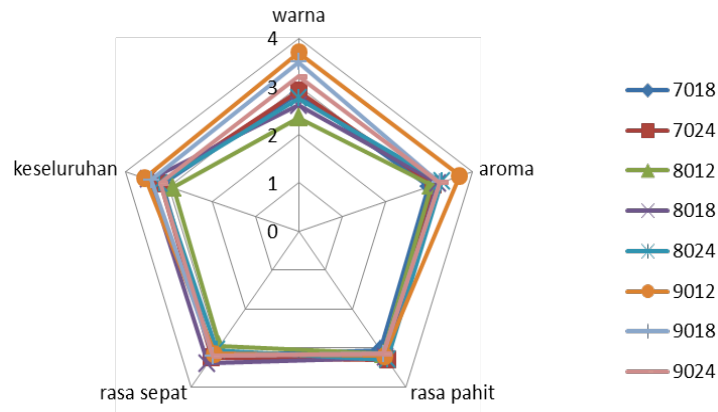

\section{Gambar 3. Hasil Uji Kesukaan Minumam Penyegar Rebusan Teh Kulit Biji Kopi Keterangan: Derajat kesukaan dinilai pada rentang $1 \mathrm{~s} / \mathrm{d}$ 5. Skor 1 . Sangat tidak suka; 2. Tidak suka; 3. Netral; 4. Suka; 5. Sangat suka}

Tingkat kesukaan tertinggi untuk atribut rasa sepat yaitu pada teh dengan suhu pengeringan 80 dan waktu 18 jam, air rebusan teh kulit biji kopi yang disukai adalah agak sepat. Rasa sepat pada beberapa produk pangan justru dikurangi sebab rasa ini tidak terlalu diharapkan. Winarno (1997) menyatakan bahwa kandungan tanin dalam teh dapat digunakan sebagai pedoman mutu karena tanin memberikan kemantapan rasa.

Proses pembentukan warna pada air rebusan teh kulit biji kopi dipengaruhi oleh senyawa penyusun kulit biji kopi serta adanya perlakuan proses pengolahan. Komponen fenol pada teh berpengaruh terhadap pembentukan warna. Selain itu perlakuan pengeringan menyebabkan senyawa fenol teroksidasi menghasilkan teaflavin dan teharubigin yang berwarna coklat.

\section{Uji Pembeda Minuman Penyegar Air Rebusan Teh Kulit Biji Kopi}

Uji intensitas atribut sensoris dari minuman penyegar air rebusan teh kulit biji kopi meliputi intensitas warna, aroma, rasa pahit, dan rasa sepat dari air rebusan teh kulit biji kopi dari berbagai perlakuan. Hasil penilaian rata-rata panelis terhadap warna (sangat coklat ke sangat hijau) minuman penyegar teh kulit biji kopi tersaji pada Gambar 4. Nilai warna tertinggi terdapat pada sampel minuman penyegar dengan suhu pengeringan $80{ }^{\circ} \mathrm{C}$ dengan waktu 12 jam sebesar 3,35 . Sedangkan nilai terendah terdapat 
pada sampel teh dengan suhu pengeringan $90{ }^{\circ} \mathrm{C}$ dengan waktu 12 jam sebesar 2,34.

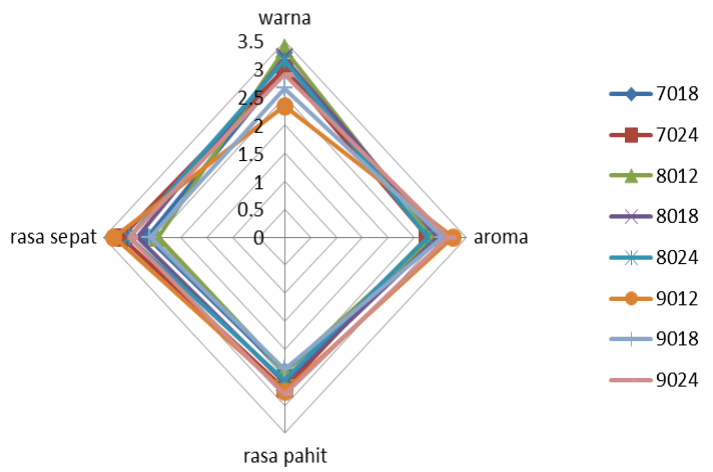

Gambar 4. Hasil Uji Pembeda Minumam Penyegar Rebusan Teh Kulit Biji Kopi

Keterangan: Intensitas warna dari skor 1= Coklat s/d 5= hijau; aroma dari $1=$ tidak beraroma $s / d \quad 5=$ beraroma teh; rasa pahit dari skor $1=$ sangat tidak pahit $s / d$ 5 = sangat pahit; rasa sepat daro skor $1=$ sangat tidak sepat $s / d$ $5=$ sangat sepat.

Dari data pada Gambar 4, menunjukkan bahwa teh yang dibuat dengan perlakuan suhu $90^{\circ} \mathrm{C}$ dengan waktu 12 jam memberikan aroma teh terkuat dan rasa sepat tertinggi. Sedangkan untuk rasa pahit, teh dengan perlakuan suhu $90^{\circ} \mathrm{C}$ dengan waktu 24 jam memberikan rasa pahit tertinggi. Perlakuan suhu dan waktu mempengaruhi nilai warna aroma dan rasa pada teh kulit biji kopi.

\section{KESIMPULAN}

Proses pembuatan teh kulit kopi hijau dilakukan secara manual dan pengeringannya dengan menggunakan oven. Teh kulit biji kopi liberika hijau yang dihasilkan memiliki warna coklat kekuningan dengan rasa sepat dan aroma agak teh. Perlakuan pengeringan pada suhu 90 ${ }^{\circ} \mathrm{C}$ dan waktu 12 jam merupakan minuman penyegar yang disukai oleh panelis dengan kadar air 5,7\%, kadar abu 4,78\%, pH 3,8, total polifenol 9,95, antioksidan 86,08 .

\section{UCAPAN TERIMA KASIH}

Peneliti mengucapkan terima kasih kepada LPPM Universitas Jambi atas bantuan penelitian dengan perjanjian Dana PNBP Fakultas Teknologi Pertanian Universitas Jambi.

\section{DAFTAR PUSTAKA}

Andarwulan, N., Fardiaz, D., Wattimena, G.A. dan Shetty, K. (1999). Antioxidant activity associated with lipid and phenolic mobilization during seed germination of Pangium edule Reinw. Journal of Agricultural and Food Chemistry 47: 31583163.

AOAC. 1995. Official method of analysis of teh association of official analytical of chemist. Arlington, Virginia, USA: Published by Teh Association of Official Analitycal Chemist, Inc.

Selvi, A.T., Joseph, G.S., and Jayaprakarsa, G.K., 2003. Inhibition of growth and aflatoxin production in Aspergillus flavus by Garcinia indica extract and its antioxidant activity. J. Food Microbiol 20 : 455-460.

Simanjuntak, L. 2014. Penerimaan Panelis Terhadap Teh Herbal dari Kulit Buah Manggis (garcinia mangostana 1.) dengan Perlakuan Suhu Pengeringan. Skripsi Fakultas Pertanian Universitas Riau. Pekanbaru.

Winarno, F.G. (1997). Kimia Pangan dan Gizi. Cet. ke-8. P.T. Gramedia Pustaka Utama, Jakarta. 